10 years ESJ

Special edition

\title{
Perpetuating Evidence in Civil Law Proceedings
}

\author{
Zurab Morchadze
}

Grigol Robakidze University, Batumi, Georgia

Doi:10.19044/esj.2022.v18n5p109

Submitted: 11 November 2021

Accepted: 08 December 2021

Published: 21 February 2022
Copyright 2022 Author(s)

Under Creative Commons BY-NC-ND

4.0 OPEN ACCESS

Cite As:

Morchadze Z. (2022). Perpetuating Evidence in Civil Law Proceedings. European Scientific Journal, ESJ, 18 (5), 109. https://doi.org/10.19044/esj.2022.v18n5p109

\begin{abstract}
The civil law process is based on the principles of adversarial proceedings and disposition, and having complete information on these principles is crucial for the parties to the process. For example, even in an apparently "profitable" case, a party who did not take care of applying the perpetuating measures may not win anything, because at the time of enforcement of the ruling it may appear that the defendant has long since alienated her/his property, or if the party has not taken care of the request for evidence and the perpetuation of evidence in a timely manner, serious difficulties may arise in the consideration of the case and as a result, lose the case. Evidence is facts obtained from sources provided by law on the basis of which the parties defend their interests. The burden of proof at trial is shared equally between the parties. The parties try to prove their veracity in order to get the appropriate result. Therefore, the main purpose of the article is to focus on the importance of the perpetuation of evidence. The first chapter deals with the essence perpetuating evidence, the second chapter deals with the judge's ruling according to which s/he can load the evidence with obligation even before the lawsuit is filed, the third chapter is devoted to the evaluation of evidence by the court and the judge's inner conviction. The fourth chapter deals with the rule of appeal, which is one of the problematic issues of this paper.
\end{abstract}

Keywords: Perpetuating, evidence, case, lost, lawsuit, decision 


\section{Introduction}

The Civil Procedure Code of Georgia was adopted on November 14, 1997, which entered into force on May 15, 1999. This Code is based on the principle of disposition and adversarial principle (Kazhashvili, 2018). In line with case law, the Code has been amended many times. At first, some parties, due to the fact that the adversarial principle was new and not accustomed to it, again demanded inquisition and more responsibility from the court in gathering evidence, in accordance with the case law, the Code has been amended many times. The principle of adversarial proceedings is much better because in this case the party cannot accuse the judge of bias (Arkhoshashvili, 2017).

The development of the adversarial principle as a principle of civil process leads to the fact that a party that does not have a professional representative is in an unequal position to the opponent (Kurdadze, 2012). The purpose of assessing the factual circumstances established in the case through the evidence is to obtain the correct conclusions about the rights and obligations of the parties (Treushnikov, 1999).

Determining the burden of proof and the admissibility of the evidence to be presented are initially defined in the claim and the response (Todria, 2010). One of the most important components of the case stage is the perpetuating of evidence. According to Article 109 of the Civil Procedure Code of Georgia, A person who reasonably considers that it would be impossible or difficult for $\mathrm{him} / \mathrm{her}$ to provide required evidence in the future, may request that the court perpetuate that evidence. Evidence may be perpetuated before a claim is filed with a court.

\section{The Essence of Evidence Perpetuation}

The role of evidence is important in civil law and with evidence the parties are asserting their rights in the process (Basilaia, 2010). Evidence can be defined and evaluated based on the factual information contained in it. (Ignatenko, 1989) Evidence has the content or information about the facts of the claim, the procedural form which is called the legal form of proof, and they are characterized by evidence information retrieval and examining evidence and means of proof defined procedural order. These three signs determine the legal nature of the court evidence. The absence of any of the named components results in a complete rejection of the evidence. Evidence, which is divided of cognitive content and procedural form, is not evidence (Gagua, 2013).

According to the first part of Article 109 of the Civil Procedure Code of Georgia, a person who has grounds to think that it will become impossible or difficult for her/him to present the necessary evidence may request that the court perpetuate that evidence. The same action can be taken before the case is initiated. This refers to cases where, for example, perishable goods are presented as evidence in a case; or even when the witness is seriously ill, and is likely to die, 
i.e. in cases where there is reason to assume that the evidence will be destroyed or lost. Thus, the person requesting perpetuation of evidence must prove that further evidence will be impossible or difficult to obtain. As Article 109 of Civil Procedure Code of Georgia, stipulates that the perpetuation of evidence is provided by the court from the moment of initiating the civil process and before the initiation of the case, the judge also has the right to take measures to perpetuate the evidence at the stage of preparation for the trial, if necessary. It should be emphasized that the range of evidence that can be perpetuated is not limited by law. An application for the perpetuation of evidence shall be submitted to the court before the case is brought. The application shall be submitted to the court of the district (city) or magistrate judge in whose area of operation (action) or territory the action is to be carried out to perpetuate the evidence. It means that there is no need to apply to the court in which the case is being heard. The statement must indicate the evidence that must be perpetuated; The circumstances for which such evidence is required; The reasons which compelled the applicant to apply to the court for security, as well as the case for which evidence is required. For example, the defendant requests the court to interrogate her/his neighbor, who may prove a fact relevant to the case indicated in the defendant's response. The neighbor is 90 years old and cannot appear in court due to a serious illness. The perpetuate of evidence is carried out in accordance with the Civil Procedure Code of Georgia (otherwise, during the hearing, materials obtained in violation of the rules of the Code of Civil Procedure will not have the force of evidence) and is manifested in the performance of a number of procedural actions (e.g., examining material evidence or questioning a witness).

\section{Evidence Perpetuation and the Decision-Making Body}

Evidence can be perpetuated both before and after the initiation of a case. The law does not provide for a case for perpetuating evidence after the case has been closed (Arkhoshashvili, 2016). The Supreme Court clarified in one of the cases that "since the proceedings are terminated and the decision has entered into force, the measure of perpetuating of evidence loses its meaning, whereas the purpose of perpetuating evidence is to establish the meaningful facts to make the correct decision. Therefore, it must be carried out before the end of the case, and in this case, when the dispute is substantially resolved, there is no longer a legal basis for such an action" (DSCG, 2008).

In fact, evidence perpetuating should be initiated before the case is brought, so that the party and her/his representative can base their hopes accordingly on the evidence they cite in their claim. Evidence is defined as activities aimed at establishing the presence or absence of meaningful facts relevant to the resolution of a case (Yudelson, 1951). The role of the court during this procedural action is crucial. While, according to the Civil Procedure Code of Georgia, the court is authorized to take the initiative to perpetuate the evidence, 
In the United States, a court will consider a party obligated to perpetuate evidence (Spencer, 2005) if s/he receives a notice about the termination or warning from the other party before the dispute (Spencer, 2005).

Only the court has the power to perpetuate the evidence. In practice, there are cases when a party submits to the court a notarized so-called Witness testimony and explanations. Such documents do not belong to any kind of evidence, according to the law of Georgia and a decision based on them is inadmissible (Kurdadze \& Khunashvili, 2012). However, there are countries where the notary or consular perpetuates the evidence before the court proceedings (Article 68.2 of the Civil Code of the Kyrgyz Republic, Article 76.2 of the Code of Civil Procedure of Kazakhstan, Article 67.2 of the Code of Civil Procedure of Tajikistan and Chapter XX of the Principle of the Russian Federation). According to the second paragraph of Article 127 of the Code of Civil Procedure of the Republic of Moldova, the notary office and diplomatic missions are the bodies that perpetuate the evidence before filing a lawsuit in court (Dmitry, 2012). In Belarus and Uzbekistan, notaries perpetuate evidence only if it is requested by other countries.

A notarized document in Georgia has legal force, as well as a notary has the authority to issue a legal document, according to which it is possible to start the procedure of enforcement. In view of the above, it would not have been unreasonable if the notary had been empowered to perpetuate the evidence that would be more convenient and easily accessible to the party. On the other hand, all this would help to popularize the institution of perpetuation of evidence which is largely dysfunctional today.

\section{Evaluation of the Evidence Perpetuated by the Court}

According to Article 105 of the Civil Procedure Code of Georgia, a court shall evaluate evidence, according to its inner conviction based on comprehensive. The judge must assess the evidence in full. A judge has no right to satisfy a plaintiff claim solely on the grounds that $\mathrm{s} / \mathrm{he}$ considers her/him a bona fide person. S/he must consider the presented motions and the evidence presented impartially and objectively (Treushnikov, 1996). Part 1 of Article 105 of the Civil Procedure Code of Georgia stipulates that no evidence is mandatory for the court in advance. This norm is especially important in relation to the conclusion of the expert. According to Article 172 of the Civil Procedure Code of Georgia, a judge does not depend on the opinion of an expert. S/he should formulate her/his opinion on the basis of an expert opinion as a result of a critical discussion (Herman, 2016).

The following applies to evidence: The probability of the veracity of the disputed statement of the parties must be objectively given and, However, the judge must be subjectively convinced of the truth of such circumstances or $\mathrm{s} / \mathrm{he}$ must not have doubts about the truth of the disputed circumstances. Thus, its inner conviction, which is free from any external influences, is the only criterion for 
evaluating evidence in civil proceedings. Therefore, the principle of free evaluation of evidence by the court has been established in civil proceedings (Eberrhard, 2010). Clearly, inner faith does not mean arbitrariness. Arbitrariness, and in particular the arbitrariness of the court, is an unfounded and unjustified position, a court internal belief, and it represents an internal, subjective criterion for evaluation. The Court Internal Belief must always be based on certain objective data, it must always be substantiated as to where and how the court formed such an internal belief as to the veracity of the evidence or its falsity.

Procedural law provides for general rules for the examination of evidence: evidence is evaluated by the court hearing the case. The court of first instance hearing the case is obliged to examine the evidence directly. The parties should be given an opportunity to express their views on the evidence in the case. The parties have the right to ask questions to witnesses, experts, specialists, as well as to each other. The court evaluates the evidence together. Accordingly, during the final evaluation of the case, the evidence must be evaluated together. Proof, this is the conviction of a judge, also subject to the laws of logic. (Davtyan, 2008) If, after evaluating the evidence, it turns out that there is a contradiction between them, the court is obliged to explain why such a contradiction exists. The court evaluates the evidence comprehensively, fully and impartially (Liluashvili, 2014).

Defining, collecting and presenting evidence is a major part of the burden of proof, which, in turn, ultimately affects the inner conviction of the trial court, the burden of proof should be interpreted as such procedural action of the disputing parties, on whose performance or non-performance it depends making a decision favorable or unfavorable for the parties to a civil case by court (Kazhashvili, 2016).

\section{Peculiarity of the Appeal against the Refusal to Use Evidence Perpetuation}

Sometimes the court has to inform the parties about this or that procedural action. That is why the statement should indicate the parties and their address, but if the evidence is to be perpetuated before the case is brought, then the statement should also indicate the defendant and its address.

Parties should be notified of the time and place of the perpetuation of evidence, but their failure to appear shall not impede the performance of a procedural action required for the perpetuation (Liluashvili et al., 2016). In urgent cases, the evidence may be perpetuated without informing the parties. Procedural action to be taken in order to perpetuate evidence must be carried out in accordance with the rules established by civil law, in particular, according to Article 113 of the Civil Procedure Code of Georgia, a judge shall deliver a ruling on the perpetuation of evidence that contains the procedures and means for its execution.

An appeal against a court ruling on the perpetuation of evidence will not be allowed. According to Article 119 of the Civil Procedure Code of Georgia a 
ruling on the refusal to perpetuate evidence may be appealed with a complaint subject to a time limit. It should be noted that before filing a lawsuit, along with the perpetuation of evidence the party files a lawsuit. In the event of a refusal to perpetuate evidence before a claim is filed with a court, the party shall file a claim in the ruling taking the court and the court have to send it to the superior court together with the case file (Kazhashvili, 2016). The circumstance is regulated differently when the court refuses to perpetuate evidence at the main hearing on the grounds that the party did not request the perpetuation of evidence for an unreasonable reason before the claim is filed with a court or at the preparatory stage of the case, although the refusal is appealed by complaint subject to a time limit. This should not be a ground for postponing the case, it should be considered together with the decision after the final decision of the case. This complaint subject to a time limit is similar to the rulings that are appealed together with the final decision. This circumstance may be due to the principle of time and economic efficiency, but in the presence of circumstances where the content of the ruling may be essential to the case, it should lead to the adjournment of the case for a period not later than two months. According to the first part of the Article 419 of the Civil Procedure Code of Georgia, a ruling on a complaint subject to a time limit shall be delivered by a court of higher instance within two months after the complaint subject to a time limit has been submitted.

\section{Conclusion}

The process of perpetuating the evidence presented in the article is one of the most important stages during court proceedings related to evidence. Its essence is so important in the civil law process, that a reasonable motion to perpetuate evidence is always a prerequisite for the successful completion of a case, which will inevitably be reflected in the court decision.

Although the above-mentioned stage is partially studied and developed in Georgia, however, for it to function complexly and effectively, it needs to be properly studied and refined from a legislative point of view. The practice of a foreign country and its adaptation to Georgian procedural law are also noteworthy, to get a more effective mechanism of perpetuation of evidence.

As demonstrated here evidence can be perpetuated before and after a claim is filed with a court. The procedure related to it is only the prerogative of the court and the notary does not have the authority to perpetuate evidence. However, there is a different lever to solve this problem, which will make judicial procedure more time-consuming and effective in useful terms. If notarial deeds are legal documents in the country and at the same time, the Chamber of Notaries is familiar with the institute of video recording of a witness, it would be better to delegate the perpetuation of evidence to notaries.

According to the Civil Procedure Code of Georgia, a ruling on the refusal to perpetuate evidence may be appealed with a complaint subject to a time limit. 
A complaint subject to a time limit shall be filed within 12 days and this period shall begin upon a ruling having been served on the party. The superior court will consider the complaint subject to a time limit and make a decision in two months (Kazhashvili, 2016). One of the decisions of the Supreme Court states that it is true that the verdict is appealed with the complaint subject to a time limit, but this should not be a reason for postponing the process and it should be considered together with the final decision. Such an approach already makes a possible differentiation of the evidence, and it is obvious that the court has some impression about them in advance. Regulating the terms of evidence and editing is possible in such a way that similar errors are eliminated from the evidence examination process.

\section{References:}

1. Arkhoshashvili L., Perpetuating the evidence in accordance with civil procedure law, University of Grigol Robakidze, file:///C:/Users/User/Downloads/147-Article\%20Text-418-1-1020130705.pdf 17.02.2021.

2. Arkhoshashvili L., Problematic issues existing in practice relating to the defendant's procedural means of protection against the claim, Tbilisi, University of Grigol Robakidze, 2016; (4).

3. Basilaia P., \#1(24)10 Results of not filling the response (objection), Justice and Law \#1(24); (17).

4. Boeling H., Chanturia L., Judicia decision - making methodology on the Georgian cases, 2019.

5. Civil procedure code of Belarus, 1998;

6. Civil Procedure of Foreign Countries, edited by Davtyan A. G. M., 2008;(26).

7. Civil procedure code of Uzbekistan Repulic, 1995.

8. Civil Procedure in Cross-Cultural Dialogue: Eurasia Context, Conference Book, Edited by Dmitry Maleshin, Moscow 2012, 352, http://ssrn.com/abstract=2280682;(352).

9. Decision of the Supreme Court of Georgia - Case - sb-258-51608 2008;

10. Eberrhard schilken-ivilprozessreccht, 2010; (229).

11. Gagua I., The burden of proof in Georgian civil procedural law, Tbilisi, 2013; (22).

12. Herman T., Evidence law, Tbilisi, 2016.

13. Ignatenko V.V., Estimated concepts in the legislation on administrative responsibility. Dis. . . cand. legal Sciences. Sverdlovsk,1989;(344).

14. Kazhashvili G., The role of the perpetuate the evidence and the role of the guarantee of the perpetuate in the proceedings, $2016(77,78,81)$. 
15. Kazhashvili G., Procedural perpetuating as a precondition for making an enforceable decision, Dissertaion, Tbilisi, 2018 (19-20).

16. Kurdadze Sh., - Performance of process peculiarities in civil law, Collection of scientific papers, Tbilisi, 2012.

17. Kurdadze Sh., Khunashvili N., Civil procedure law of Georgia, Tbilisi, 2012;(238,239).

18. Law of Georgia, Civil procedure code, Consolidated version, https://matsne.gov.ge/ka/document/view/29962?publication=144, $17 / 02 / 2021$.

19. LiLuashvili T., Khrustali V., Commentary on the code of civil procedure, Second revised edition, Tbilisi, 2007; (224).

20. Liluashvili T., Liluashvili G., Khrustali V., Dzlierishvili Z., Civil procedure law, Tbilisi, 2014;(94,229,230).

21. Recommendations on civil, administrative and criminal matters developed as a result of regular meetings of judges in the Supreme Court of Georgia. Uniform practice of the Supreme Court of Georgia relating the civil and administrative cases, publication of the Supreme Court of Georgia, Tbilisi, 2006.

22. Spencer A.B., The Preservation Obligation: Regulating and Sanctioning Pre-Litigation Spoliation in Federal Court, 79 Fordham L. Rev. 2005 (2011), 2009, http://ir.lawnet.fordham. edu/fl r/vol79/iss $5 / 7$.

23. Todria T., Dissertation, Ivane Javakhishvili Tbilisi State University, Significance of the factual circumstances in the Court of Cassation, Tbilisi University Press, 2010;(16).

24. Treushnikov M.K., Judicial evidence, M.,1999;(161).

25. Treushnikov M.K., prof., doctor of juridical sciences - Chrestomathy on civil procedure / moscow - 1996;(94).

26. Yudelson K.S., Problems of proof in Sov. Civil process, M,1951;(115). 